\title{
AMERICAN DEMOCRATIC SUPPORT TO GHANA'S FOURTH REPUBLIC: ASSISTANCE OR ENCUMBRANCE?
}

\author{
Isaac Owusu-Mensah \\ Isaac Owusu-Mensah is a lecturer in \\ the Department of Political Science at the University of Ghana \\ email: iomensah@ug.edu.gh
}

\begin{abstract}
The end of the Cold War ushered the world into a new era of democratic governance. Citizens in developing countries began to actively contribute to the democratic process, by demanding probity and accountability in existing governance structures. The international donor community added to these efforts by responding to the challenge of the new wave of democratisation in the late 1980s, by embracing 'democracy assistance' as a core priority. In January 1993, Ghana inaugurated its Fourth Republic. It was a transition fraught with challenges - which continue to blight the development of a democratic culture. In response, the American Government stepped in with financial and technical support in the hope of helping Ghana to avoid a stall in the county's democratic development. This aid for democratic development has received plenty of criticism with regard to issues such as as conditionalities imposed by America. The current study used a matched-area comparison to examine the effects of aid programmes. The findings show that the USAID-initiated ECSELL and GAIT programmes have increased local-level democratisation in Ghana by strengthening the capacities and abilities of civil society.
\end{abstract}

Keywords: America, Ghana, democracy, democratic support, civil society.

\section{INTRODUCTION}

The people of Africa wholeheartedly supported the struggle for independence against colonial rule and foreign domination. The notion of African independence 
was full of promises and hopes that Africans would become the masters of their own destinies and fulfil their dreams for a better life. Independence was expected to boost socio-economic development and put an end to squalor, superstition, avoidable disease, ignorance, malnutrition and poverty. Africans would be in charge of their own affairs, and decisions would be built on African ways of building consensus. Such hopes, however, have shown themselves to be dependent on the ability of a country to democratise itself. This is because economic growth requires a certain level of sustained income and productivity (Mobarak 2005, p. 1).

Ghana became independent in 1957. Since then, the country has embarked on four attempts to achieve a workable democratic government. In 1959, it emerged as one of the first (de facto) post-colonial one-party states in tropical Africa. In 1969 , after experiencing a military coup d'état, Ghana led the region by returning to constitutional government in its Second Republic. In 1979, it transitioned to its Third Republic. In January 1993, the country again set a precedent when it became the first sub-Saharan country to elect a democratic government for the fourth time. With the establishment of Ghana's Fourth Republic, a true democratisation process had begun. However, the process was - and still is - fraught with challenges which blight the development of a democratic culture.

Ghana was not alone in this process of democratisation. By the end of 1990, as a result of the end of the Cold War, most African countries with autocratic regimes had begun to liberalise themselves. The impetus came either from domestic or international pressure. These countries were moving towards participatory democracy, where citizens could, through periodic elections, hold leaders to account for their action or inaction (Clapham 1993, p. 424). However, despite the desirable prospects of good political governance thriving in Africa, the continent has failed to reach its full potential. This failure is the result of the huge demands in terms of human, material and technical resources required within the democratic process (Chabal 1998, p. 191). Such resources have failed to be attained by many African governments because of a wide range of social, political and economic problems.

These problems include continual war, extreme poverty, worsening terms of trade, drastic reduction in social welfare programmes, rising unemployment, rampant corruption and economic mismanagement, inadequate and inappropriate policies and practices, poor distribution mechanisms, deteriorating infrastructures, and the ravages of AIDS and other pandemic diseases (BoafoArthur 2008, p. 52). These social, economic and political demands and realities greatly impinge on the national governance budget in respect of institutions that are mandated to develop democracy. This situation leaves political actors 
with limited funding options for supporting state governance institutions. As a result, civil society groups must step in to support the flagging performance of governance institutions.

In an effort to address these resource constraints and to support the process of democratisation, international aid has become a constant - and in many ways necessary - support mechanism. Historically, Africa has received more per capita aid from the international community in the form of official development assistance than any other region in the world (Leonard \& Straus 2003). According to Diamond (2004, p. 263), by the late 1990s, well over half of all African states were receiving $10 \%$ or more of their Gross National Product (GNP) from foreign aid. Foreign aid accounted for over $50 \%$ of African government revenue, and for $71 \%$ of public investment. Leonard and Straus (2003) calculated that most African countries received more in development assistance than they collected in tax revenue.

Such dependence on external financial aid to support government processes remains a stark reality for several African countries that are transitioning to, or are maintaining, democratic rule. This fact has created a split in opinions about whether external support in the form of donor aid is a help or a hindrance to the process of democratisation.

The United States of America (US) is a major player in providing donor aid to support the democratisation process in other countries. The US began channelling funds and resources to Ghana's democratisation process in the form of USAIDfunded projects. However, questions have arisen over American interventionist strategies and actual intent because of conditions attached to aid (Brown 2005, p. 180). Some scholars (Djankov et al. 2008, p. 169; Goldsmith 2001, p. 125; Knack 2004 , p. 252) argue that foreign aid does little to promote democracy. However, others (e.g. Finkel et al. 2007, p. 405) continue to affirm that American aid strategies do promote democracy.

The central issue examined in this paper is the effect that democracy assistance has had on the democratisation process in Ghana's Fourth Republic. The specific research question was as follows: what effect has American support designed to promote civil society had at the local level in Ghana? In addressing this question, three main factors were considered:

- the extent to which such resources can mobilise civil society into political action;

- the extent to which these funds support the effectiveness of civic groups to function at the local level; and

- the extent to which this assistance supports capacity building and networking by civil society within local governance. 
Despite criticisms of American aid initiatives, such support for Ghana's democratisation process has proven to be successful at the local level of governance. The author reached this conclusion after studying two USAIDfunded programmes, both of which were designed to increase transparency and accountability in District Assemblies (DAs) and to increase the ability of Civic Unions (CUs) to advance the cause of other members of civil society in Ghana. The two programmes in question were Enhancing Civil Society Effectiveness at the Local Level (ECSELL) and Government Accountability Improves Trust (GAIT).

\section{METHODOLOGY}

The study used a sequential mixed-methods approach to solicit information from the selected respondents. Strict methodological standards were applied when selecting the respondents, to increase the likelihood that views expressed by the sample group would reflect widely held views among the Ghanaian general population. Some stratification and multi-phase sampling procedures were used to identify suitable respondents.

Two methods of data collection were used to gather data during the fieldwork stage. These methods were, respectively, a questionnaire survey and structured interviews. This primary data collection was divided into three phases as follows:

1. Interviews were held at the offices of USAID and other implementing agencies, such as the International Foundation for Election Systems (IFES), the National Democratic Institute for International Affairs (NDI), and the Cooperative League of the United States of America (CLUSA). This leg of the investigation used structured interviews. Fifteen Respondents at the American Embassy and USAID offices in Accra, as well as other democracy-assistance bodies in Ghana, were interviewed.

2. The second phase involved the administration of 200 questionnaires (i.e. the survey), of which 165 questionnaires were returned fully completed, at the DA level. The survey was targeted in areas of Ghana where USAID had implemented democracy assistance programmes. The country was divided into three clusters for the purpose of this study, as follows:

- Cluster 1: Northern Ghana - made up of Upper East, Upper West and the Northern Region.

- Cluster 2: contained the middle belt, comprising the Brong-Ahafo Region and the Ashanti and Eastern Regions.

- Cluster 3: Southern Ghana - made up of the Volta, Greater Accra, and the Central and Western Regions. 
Purposive sampling was used. Respondents were drawn from the Nadowli, Wa and Damango districts to represent the Northern cluster; from Berekum and Techiman to represent the middle belt; and from Ga, Dangbe East and Dangbe West to represent Southern Ghana. The selection of the districts was determined after critical demographic and political assessment of the features of the districts. The district selection process was also influenced by voting patterns, by the vibrancy of civil society activism, and by overall relations between DA and society. The selection of districts was further influenced by the implementation of the ECSELL and GAIT programmes. For each cluster, one district that benefited from both programmes was selected, as well as a district that benefited from a single programme only. Structured interviews and the survey questionnaire were done at both the community and district levels.

3. The third phase involved interviews with eighteen DA staff made up of District Coordinating Officers, Planning Officers and Finance Officer. The researcher sought the views of Assembly staff who were directly involved in the project as well as staff who were not connected to the project. The aim of the interviews was to gain holistic information about the project. A secondary aim was to appropriately integrate the official perspectives, representing the state, with data collected from civil society, to ensure a balance. The interview data collected were then systematically analysed through coding and categorising of the information solicited from the district offices across the country.

Secondary sources of data collection included official documents at the Assemblies, offices of IFES, GAIT and USAID, certain Civil Society Organisations (CSOs), implementing agencies, and other stakeholders who contributed to the democratic transition and consolidation in Ghana. These documents were reviewed for relevant information. Annual reports, evaluations and various assessment reports were also reviewed.

The following perspectives outline the direction and framework of this paper.

\section{THEORETICAL FRAMEWORK}

Democratisation theories are central debates within political thought (Dahl 1997; Drah 1993; Ninsin 1993). Democratisation theories which focus on the relationship between a country's level of democratisation, or its ability to democratise, and the mechanisms that support this process are especially important (Dahl 1997; Drah 1993; Ninsin 1993). Theorists have examined specifically the conditions which make regimes or political systems more vulnerable to manipulation by the political elite, and whether such factors affect the level of democratisation. 
Generally, theories are divided into those that focus on internal or external factors, and theories about factors that influence democratic development.

\section{Domestic / Internal Theories}

Structural theory suggests that the existence of structural prerequisites disposes a society towards democracy (Lipset 1959; Vanhanen 1990). Once certain conditions are met, democracy flourishes. The corollary is that the absence of these fundamentals undermines the growth of democracy. Accordingly, a country's democratisation can be accelerated by developing aspects of complex characteristics of economic and social structures within the context of legitimate economic development (Lipset 1959). For example, there is a significant relationship between the educational, religious and income levels of a country and that country's expected democratic progress or level of democracy. Thus, it is argued, democratisation is best achieved by internally developing social structures (Midlarsky 1997; Olson 1993).

By comparison, proponents of cultural theory (e.g. Almond \& Powell 1993; Almond \& Verba 1963; Diamond 1992; Inglehart 1988) explain the emergence and growth of democracy - or the lack thereof - in a country by identifying three types of political culture. These are i) parochial culture, which refers to a situation where citizens are not aware and do not participate in the political system; ii) subject culture, where people are aware of the political process but do not participate in the system; and ii) participant culture, where people are aware of the political process and system, and participate in them. A mix of these scenarios constitutes the civic culture of a society, which determines 'associational behaviour, tolerance, and interpersonal trust' (Al-Momani 2003, p. 45).

Thus, certain cultural practices promote democracy whereas others obstruct its growth. In contextualising the cultural perspective, Maxwell Owusu (1972) observed that 'political culture' encompasses the total environment of ideas, beliefs, perceptions, attitudes, values, judgments, sentiments and expectations. All these factors shape, define and sustain the relationship between the leaders and the led, and between politicians and constituents.

By contrast, process theorists (e.g. Huntington 1993; Przeworski 1986; Rustow 1970) explain democracy as the end product of several developmental stages. Economic growth is seen as leading to political development, which in turn transitions into modernisation and ultimately democracy. Such processes require a country to follow these sequenced transitions, which according to Huntington (1993, p. 5) take a long time. Deviation from this process would impede the growth of democracy. 
Within process theory, Rustow (1970) and Przeworski (1986) emphasise the catalytic role of elites in the democratisation process. The power held by elites ensures their influence on societal conditions and rules and on changes to formal and informal structures of the political system. Thus, for democracy to thrive, elites must agree on democratic goals and norms as a mechanism for the distribution of power and resources in society. They must also agree on an effective system through which to institutionalise conflicts (Przeworski 1986, pp. 41-63).

More relevant to this study, however, are theoretical perspectives which focus on external dimensions of democracy promotion.

\section{International / External Theories}

The external dimension of democratisation is explained by two theories: military interventionism and financial theories of democratisation. These two theories are the principal blocks to explain how external support can aid the democratic development of a country. American support for Ghana's democratic development must be explained within the context of one of these theories.

Military intervention theory is based in realism. It views the behaviour of states as the pursuit of national interests governed by the use of power; specifically, democracy is obtained through external intervention (Talentino 2005, p. 19). The use of power by an external force to bring about regime change is justified by the contention that the regime is illegitimate. According to military intervention theory, a state can employ any means to pursue its foreign policy objectives, so long as such means are in line with the overriding goal of security and survival (Evans 2006). Direct military intervention is mainly used for the purpose of national survival or high-priority goals, such as humanitarian grounds and the promotion of human rights. Usually, direct military intervention is a last resort to achieve foreign policy objectives, as it is seen as both expensive and risky to implement (Evans 2006).

The theory of military interventionism has its roots in Thucydides through Machiavelli. However, it has been discredited in democracy literature as a coercive tactic used by rich, powerful, industrialised states to exert power over poorer or less powerful states (Lowenthal 1991). The aim is to compel the poorer states to act in a manner that is in the interests of rich countries or to behave in a manner that powerful nations consider permissible in the international system (Jamieson 2005). This stance is supported by Lowenthal (1991), who studied America's use of military intervention as a foreign policy tool. According to Lowenthal (1991, p. 261), American 'efforts to promote democracy through military intervention have generally yielded negligible, often counterproductive, and only occasionally positive results'. Similarly, Whitehead (1991, p. 234) argues that there is a grave 
contradiction in one state trying to compel other independent states to be free. According to Whitehead (1991), democracy must be built on the foundation of popular sovereignty and freedom of the people to determine their own future, rather than being imposed by outsiders.

By comparison, theories of financial transfer examine the use of financial and technical aid by an external agent to stimulate the growth of democracy (AlMomani 2003). Financial transfer theory suggests that states are able to determine and influence the political systems and classes of other states, without the use of military intervention, even to the extent of changing a regime (Al-Momani 2003). Thus material resources rather than military might are capable of changing ideas, ideals and values. Financial transfer theory includes two strategic theories of democratisation: foreign direct investment (FDI) and foreign aid.

Foreign direct investment is an investment which a foreign individual or organisation makes towards the productive capacity of another country. It involves the transfer of assets or intermediary products within the investing enterprise, without any change in ownership. The theory of FDI suggests a direct correlation between a country's level of democratisation and FDI made into that country (Quan \& Resnick 2003). While FDI itself does not initiate democracy, it facilitates the development of democratic institutions, such as structural features of the recipient country, as a dividend of good governance.

A country's ability to attract FDI depends on the nature of its political system or governance (Quan \& Resnick 2003). Investors generally consider a political system whereby established institutions, such as an independent judiciary, work to protect the economic system - including their investment - through adjudication of cases. As a result, developing African nations have acceded to assessments such as the African Peer Review Mechanism to advertise their democratic credentials. This is one way to persuade investors. Olson (1993, pp. 567-576) argues that criteria such as an independent judiciary and electoral programmes help to guarantee property rights, and hence ensure that investments are secure in the long term. Investors favour such regimes because their assets are shielded from predatory dictators.

By contrast, O'Donnell and Schmitter (1986) suggest that rather than supporting democratisation, FDI hinders such growth. This is due to the intimate relationship between investors and political leaders. Competition for investment ensures that investors receive preferential treatment with regard to wage, labour and taxation leeway, at the expense of the rights of the country's own citizens (O’Donnell \& Schmitter 1986).

The second component of financial transfer theory is foreign aid. This aspect of the theory posits that developed democracies provide direct and indirect material and technical assistance to transitional countries to sustain the latter in 
building a democracy. Such assistance would include the development of credible elections and democratic institutions, with the aim of invigorating democratic growth (Garvey 1966). Williamson and Haggard (1994, p. 526) considered foreign aid to be an external incentive to reward new and growing democracies during the embryonic stage; foreign aid also supports regimes in stabilising their internal politics and thus supports citizen rights.

Apodaca and Stohl (1999, pp. 185-198) examined the relationship between human rights and American bilateral foreign aid over a period of nineteen years (1979 to 1996). They used 'foreign aid' as the independent variable and 'human rights record' as the dependent variable. They concluded that with the exception of the Clinton administration, human rights played a critical role in determining whether a country qualified as a good candidate to receive aid and the amount of aid received (Apodaca \& Stohl 1999, p. 197). Regan (1995, pp. 613-628) used a similar framework to investigate the effect of aid on changes in human rights records among countries supported by the Reagan and Carter administrations. Regan's study showed that neither economic nor political aid had a discernible effect on the human rights record of a recipient country, and did not determine its political system.

Similarly, Al-Momani (2003) assessed the effect of American foreign aid on emerging democracies over an eighteen-year period (1976 to 1994). The scope of the study was large: 174 developed and developing countries were included. The findings showed that international financial transfers had relatively little effect on a country's level of democracy (Al-Momani 2003). Finkel et al. (2006) also studied the effects of American democracy assistance on democracy-building, specifically the growth of democratic values and institutions. The scope of this study was again broad, with 195 countries studied over thirteen years (1990 to 2003). Finkel et al. (2006) concluded that there was general growth among all the countries studied, and that foreign aid had only a modest effect on democratisation (Finkel et al. 2006).

Despite these findings, the author posits that foreign aid theory is best suited to evaluate the effect of American aid on Ghana's democratisation process. The role of American aid is evaluated by regarding it as the independent variable, and growth in democratic development in Ghana is regarded as the dependent variable. Using this model, conclusions are drawn about the effectiveness and validity of such support.

\section{DEMOCRACY AID DEBATES}

The funding of democratisation is the international donor community's response to the challenges of the new 'wave' of democratisation which started in the 
late 1980s (Santiso 2000, p. 1). By embracing democracy assistance as one of its core priorities, the international donor community actively shapes national democratisation processes. Diamond et al. (1999, p. 171) suggest that such molding is proactive:

[p]erhaps the most distinctive feature of the third wave ... is the considerable contribution that international actors have made to democratic development by enhancing the resources, skills, techniques, ideas, linkages and legitimacy of civil society organisations, civic education efforts, the mass media, legislatures, local governments, judicial systems, political parties, and elections commissions in the developing and post-communist worlds. The prospects for democracy in the world will be much brighter if these many currents of practical engagement are sustained, refined and widened.

The catalogue of programmes targeted by democracy assistance is extensive. It ranges from assistance to support free and fair elections to the reform of government institutions through constitutional engineering, and from security sector reforms to the strengthening of civil society organisations (Crawford 2001, p. 89). While certainly each of these can be proactive steps towards democratisation, motives behind their implementation and the way in which such programmes are carried out determine the actual benefit to the recipient country and its citizens (Carothers 1997, p. 110).

According to Diamond (2004), international donors have increasingly provided aid to support democracy since the end of the Cold War. Diamond theorises that aid to the developing world is driven by a long-standing development model which assumes that the missing key ingredient for development is finance. This developmental economic model further postulates that if external donors provide the needed resources to fill the gap between a country's own capacities and the required level of investment, economic development will take place (Diamond 2004, p. 264).

By contrast, Karl (1997) cites examples from Nigeria, Angola, the Democratic Republic of Congo and Cameroon to argue that the core problem which obstructs economic development in Africa is not a lack of resources, although that is indeed a grave quandary for many African countries. Karl posts that the main challenge is the inefficient management and allocation of available resources to ensure equal benefit among citizens. What is required is therefore a well-developed system of checks and balances rather than a continual influx of funds (Karl 1997). 
Despite the differences between these theories about the democratic process, what is apparent in both positions is the idea that a country's democracy is intricately linked to its ability to develop economically. This position was certainly the basis for policies such as the Structural Adjustment Programmes (SAP) of the 1980s. However, the results of such programmes suggest that this type of development practice may be at odds with the knowledge-based economy of the $21^{\text {st }}$ century. None the less, the funding of democracy by stimulating the economic development of a country has continued across the world. According to Carothers (2000), since the mid-1980s the American Government has devoted US $\$ 500$ million per year to fund programmes that promote democracy globally. The resources that are given range from small-scale civic education assistance to massive multilateral collaboration. These resources are meant to fund programmes to strengthen democratic institutions, processes and ideals in the target countries.

\section{AMERICAN DEMOCRACY ASSISTANCE AND FOREIGN AID}

The genesis of America's international development assistance can be traced to the end of World War II. At that time, the European Recovery Programme of 1948, also known as the Marshall Plan, was formulated. The Marshall Plan was motivated by a mix of humanitarian concerns, strategic efforts to limit Soviet influence in Eastern Europe, and the need to restore the European market for American goods (Zimmerman 1958, as cited in Hanson 1991).

By October 1951, America's focus had shifted to providing military aid and defence assistance. To a lesser extent, economic and food aid were given in the form of the Mutual Security Administration (MSA). Fears about communism, both real and imagined, fuelled the growing importance of the MSA (ibid). Economic project components of the MSA were designed to subvert the spread of communist ideals, with large sums of money being spent on building the economic structures and political allegiances in other countries that were deemed necessary to support this goal (ibid). It was not until the start of the 1980s that democracy promotion became one of the four core priorities of America's foreign aid programmes (Carothers 1997, p. 120). While the rise of democracy aid during that period was the result of President Reagan's anti-communist policies, all successive American governments have followed the same foreign policy.

\section{Models of Implementation}

The programme of democracy embarked on by America is characterised as institutional modeling. The philosophy of institutional modelling is to nurture socio-political institutions of democracy in a developing country, in a manner that resembles the counterpart of those institutions in western countries (Carothers 
1997). According to Carothers (1997, p. 116), democracy assistance is meant to facilitate such modelling processes. However, the strategy of institutional modelling faces two limitations to democratic development: Americanisation and the failure to recognise local political structures. Campbell et al. (2004, p. 11) define Americanisation as follows:

The cultural, political and economic influence of the USA which shapes the way in which people perceive and understand difference. Thus, democracy assistance aims to strengthen endpoints of institutions to function with the requisite inputs and resources in a form similar to that in the US without consideration of alternative forms and types of democracy suitable peculiar country.

American democracy support promotes an independent and robust legislature, which oversees the responsibilities and actions of the executive branch of the government. According to Campbell et al (2004), further elements of the American model of democracy promotion abroad include -

- increasing accountability through avenues such as alternative media outlets (that is, private ownership of media as an alternative to government-owned operations);

- detaching race and religion from political affiliation; and

- strengthening the capacity of trade unions to increase their bargaining power.

However, adhering to this framework of power division and the separation between state and private concerns means that policy-makers discard and devalue the distinctive qualities of cooperation between the legislature and the executive. Boafo-Arthur (1998) argues that such cooperation is essential in the early stages of democracy promotion. Thus, adopting the American framework can be detrimental to a country's successful transition to democracy. This was the case in Ghana in 1979, where as a result of the separation of power, the national budget and economic policy were not approved by Parliament. In addition, privatising a broadcasting system detracts from the citizens' inputs obtained through public ownership.

The second flaw in the democracy-support framework is its lack of recognition of and appreciation for the local power structures of the recipient country. Evaluating the local structures of beneficiaries which receive democracy aid is an essential step in ensuring appropriate outputs (Carothers 1997). This step, however, is often missing in the American strategy. The sociological, economic and 
political factors and actors which shape local institutions are typically relegated to the background in pursuit of democracy promotion activities. Instead of evaluating and working with local institutional structures, American democracy assistance is given under conditions defined by American roles and strategies. This paper looks critically at the above issues in American democracy aid to evaluate such aid to Ghana's Fourth Republic.

\section{AMERICAN DEMOCRACY AID TO GHANA}

The success of Ghana's transition to the Fourth Republic, compared with its previous three attempts, is credited to the huge financial support the country received from the international community (Boafo-Arthur 1998, p. 16). BoafoArthur (1998, p. 17) argues that the extent of support from external partners raises doubt as to whether the Provisional National Defence Council (PNDC) would have continued with the transition programme without the involvement of the donor community. Although such assistance seems to have been necessary for the transition, its impact continues to be debated, especially in the face of a simultaneous growing economy and rising inequality among Ghanaians.

As Ghana moved towards democracy, civil society and state institutions both played a significant role in the process. Pro-democracy projects and programmes with the aim of contributing towards free and fair elections had to be organised, and citizens had to be educated about their fundamental human rights, and about their responsibility to strengthen governance institutions. Programmes run by state and non-state actors required huge resources from various stakeholders (Hearn 1997, p. 11). But local stakeholders' internal structures were frail, and financial resources for pro-democracy actors to realise their objectives were limited. This necessitated external support for the country's democratisation process.

Gyimah-Boadi (2004, p. 126) argues that international development partners refocused development assistance, shifting a pro-state focus to one which supported the development of civil society and other non-state institutions. This refocus resulted from the growing importance that civil society plays in holding the state accountable (Gyimah-Boadi 2004, p. 126). Bilateral and multilateral agencies used the opportunity to enhance democratic development. According to Carothers (1997, p. 121) during the post-Cold War era, the funding arena changed. Previously aid had been given directly to state institutions for economic development, whereas now civil society organisations were encouraged to actively participate in the democratic process. As a result, the American Government and various US-based organisations provided support to promote democracy in Ghana through civil society organisations (CSOs) and the American State Department. 
One example was the American Embassy in Ghana and the US Agency for International Development (USAID).

Table 1 below is based on a USAID report, and shows how democracy aid given by America to sectors in Ghana was refocused between 1994 and 2003. Initial democracy funding was targeted at the electoral system development, with USAID and its implementing agencies investing vast resources to build a credible electoral platform for democratic development and growth after several years of military rule. The controversies which had surrounded the 1992 presidential and parliamentary elections had contributed to this need. Assistance to civil society started with small amounts in 1995 and gradually climbed to compete with other sectors of democratic development.

Table 1

Sectoral distribution of democracy support to Ghana, 1994-2003 (US\$ million)

\begin{tabular}{|l|c|c|c|c|}
\hline Year & Elections & Rule of Law & Civil Society & Governance \\
\hline 1994 & 2.55 & 0 & 0 & 0 \\
\hline 1995 & 4.35 & 0.39 & 0.2 & 0 \\
\hline 1996 & 2.24 & 0.39 & 0.31 & 0.01 \\
\hline 1997 & 0.44 & 0 & 0.38 & 0.64 \\
\hline 1998 & 0.07 & 0 & 0.51 & 1.02 \\
\hline 1999 & 0.54 & 0 & 0.59 & 0.83 \\
\hline 2000 & 0.47 & 0 & 0.63 & 0.82 \\
\hline 2001 & 0 & 0 & 0.49 & 0.93 \\
\hline 2002 & 0 & 0 & 0.58 & 0.76 \\
\hline 2003 & 0 & 0.04 & 0.86 & 0.51 \\
\hline
\end{tabular}

Source: USAID Report of Assessment of Effects of US Foreign Assistance on Democracy Building 1990-2003

Although the inclusion of CSOs in democracy-funding initiatives was a welcome shift in funding arrangements, it remained rhetoric rather than reality. The funding agency rather than recipient still largely controlled the implementation of such programmes. American non-governmental organisations (NGOs) such as the International Foundation for Elections Systems (IFES) and the National Democratic Institute for International Affairs (NDI) became the implementing agencies of USAID democratic support to Ghana. The office of USAID argued that there were 
no developed, experienced and credible local pro-democracy NGOs in Ghana which could implement its programmes (Hansen 1996). This understanding of the capacity of Ghanaian NGOs and CSOs coupled with the new focus in funding led the USAID to initiate, through its partners, two projects to enhance the development of civil society at the local level. These projects were started between 1996 and 2009, and were called Enhancing Civil Society Effectiveness at the Local Level (ECSELL) and Government Accountability Improves Trust (GAIT).

\section{Enhancing Civil Society Effectiveness at the Local Level (ECSELL)}

ECSELL was a project designed by USAID and implemented by the International Foundation of Elections System (IFES). The project was a follow-up to political and election-related programmes that had been implemented by IFES on behalf of USAID under a cooperative agreement called 'Supporting the Electoral Process' (STEP). The ECSELL project was a political capacity-building venture which aimed to increase the capacity of civic groups to achieve their primary goals, and to advocate and improve local government responsiveness to citisens' demands. Its main aim was to strengthen the link between civil society and local government units in selected districts through training and small grants.

The project also aimed to help groups to create civic engagement programmes with their respective DAs. Through IFES, USAID gave democratic assistance to civil society groups in all of Ghana's ten regions, working in twenty of the 110 districts. The beneficiary organisations and groups had limited contact with the main benefactor (USAID).

For the purpose of implementing its broad national programme, USAIDGhana classified civil society groups into the following categories: development organisations, trade unions, advocacy groups, and service providers. This classification was adopted by IFES because it promoted the inclusion of a broad segment of civil society.

The IFES conducted a baseline study to evaluate challenges to the development of civil society at the local level, in particular. They also evaluated problems in local governance in Ghana with reference to DAs. The IFES reviewed civil society with regard to levels of funding, the degree of internal democracy, and relations with the DAs. The IFES also examined the status of CSOs' internal operations, the quality of their relations with national government, and the extent of their engagement with civic groups in the district.

After the assessment stage, the IFES addressed problems that were impeding the development of civil society at the local level. It provided training in basic management skills for civic leaders and local government officials, to facilitate their collaboration in solving problems facing the district. 


\section{Government Accountability Improves Trust (GAIT)}

The GAIT project was a continuation of the USAID civil society empowerment programme which had begun with the implementation of ECSELL in selected districts. The aim of GAIT was to strengthen the management and organisational capabilities of civil society organisations so that they could become effective partners in local governance and contribute to national policy formulation. The GAIT project was implemented by the Cooperative League of the United States of America (CLUSA).

The name change (ECSELL to GAIT) resulted from a shift in the policy direction of the project. In ECSELL the focus was on the regular participation of civic groups in the decentralisation process, but with GAIT this focus shifted to include the accountability of public office-holders in the districts. The GAIT project aimed to continue the work of ECSELL, but with the added element of increasing the accountability of government stakeholders. The project was implemented in two phases, Phase One being 2011 to 2004 and Phase Two being 2005 to 2009.

The second phase of GAIT (GAIT II, 2005-2009) progressed from fostering partnerships between civil society and local government to include community participation in education. The selection of districts to participate in GAIT II was based on competitive bidding to encourage full participation of CUs and DAs. Proposals were jointly submitted and defended by a team made up of CUs and the DA. The overall aims of GAIT were as follows:

- to increase the capacity of Ghanaian CSOs to advocate the interests of their members at local government level;

- to promote transparency, accountability and anti-corruption in local governance institutions;

- to increase voter turnout; and

- to increase political participation of CSOs at all levels of government.

Strategies to meet these objectives involved boosting the capacity of CSOs in the areas of planning and management; promoting CSO networks; establishing discussion platforms between key CU members, DA members and citizens; and providing modest matching grants by GAIT to CUs.

\section{RESULTS AND DISCUSSION OF RESEARCH}

ESCELL Project

Strengthening the capacity of civil society to meet primary goals of members

Despite the importance of a strategic plan to the development of a civic entity 
(Pearce et al. 1987, p. 658), fewer than 5\% of the civic groups that IFES met with across the country had prepared strategic plans prior to the ECSELL project (Baseline Report of Civil Society Organisations-IFES, 1999). As a result their management practices were precarious.

As a first step, IFES offered management training programmes to the leaders and members of civic groups, at different levels, with modules on strategic planning and implementation. The Hair Dressers and Beauticians Association of Nadowli and Fian Women's Groups were among the beneficiaries. The aim was to give the groups basic management tools. The IFES asked the civic groups to assess how well their operations worked in the absence of strategic plans. The IFES then supported the groups to draw up strategic plans so that they would be able to assess and articulate the concerns of citizens in their regions. By the end of the project, $79.2 \%$ of the civic groups which had participated had drawn up modest strategic plans for their organisations to ensure they could achieve their main objectives.

\section{Strengthening the capacity of CSOs to advocate}

The capacity of civic groups and CUs to advocate was measured by the following three indices: improvement in internal democratic practice, linkages with other civic groups, and ability to mobilise resources.

\section{Improvement in internal democratic practice}

Civil society organisations which promote democracy as part of their external goals must also demonstrate internal democratic practice within the organisation; this gives a necessary political legitimacy for their activities (Brysk 2000, p. 151). This study examined the committee elections and decision-making processes as a way of measuring the extent of a CSO's internal democracy. The study assessed the electoral process of each association that was a member of the CUs in the selected districts.

Of the 28 associations interviewed, 75\% selected their leaders through elections. About $25 \%$ of the associations indicated that before the projects had intervened, their organisational elections had been irregular or absent. The researcher was unable to ascertain how free and fair the internal elections were. However, secondary sources from the respective district electoral offices suggested that Electoral Commission (EC) officers had supervised all of these elections.

A second feature of liberal democracy is the decision-making structure of an organisation, which indicates the extent of articulation and aggregation of individual voices (Owusu 1972, cited in Boafo-Arthur 1993, p. 114). An organisation is undemocratic when the leadership controls the decision-making process. This study finding shows that members are actively participating in 
decision-making within their organisations. There were comprehensive decisionmaking arrangements within the civic group:

- $3.6 \%$ of the civic groups made decisions through their executive committees and by consensus;

- $21.4 \%$ of decisions were made by the entire membership of an association (averaged across all associations studied);

- $71.4 \%$ of members of the associations studied said that general members in association with the executive committees made decisions.

Participation in the decision-making process increases people's sense of ownership of that process. Additionally, it allows the organisation's leaders to educate members about current conditions and the results of decisions. The findings of this study suggest that civic organisations that had implemented the ECSELL programme had developed internal organisational democracy, and provided the required space for their members to participate in governance.

\section{Development of networks and linkages}

This study showed that $55.6 \%$ of civic groups had belonged to a vertical network before ECSELL was introduced. After participating in ECSELL, 87.5\% of these civic groups were integrated into at least one network, either horizontal or vertical. As part of ECSELL, artisans and professional group bodies had joined their resources to champion a common cause, such as the collection of revenues on behalf of the DA. The networks equipped members with skills and knowledge to improve their efficiency, and broadened their understanding of governance through events such as visits to Parliament.

Through ECSELL, a number of civic groups such as Feo Leather Workers Association in Bongo and the Butchers Association in Wa established intra- and inter-professional networks. Although some professional groups had already belonged to relevant national associations, participating in ECSELL provided organisations with new impetus to redefine their mandate and direction. Civic groups from the ECSELL districts were able to properly articulate and aggregate interest among their members.

\section{Ability to mobilise resources to promote primary objectives}

The ECSELL project fostered collaboration between the state and civic groups. The small grant component of the project, for example, was jointly administered by civic groups and their respective DAs. Following various training programmes 
conducted by IFES, small grants of roughly US $\$ 400$ per grant (on average) were disbursed to 78 civil society groups, representing $36 \%$ of civic groups that had applied for support in the 20 selected districts in the country.

The IFES provided a total of US\$ 32000 in small grants to civic groups (IFES 2006). Six CUs and 72 individual civic groups benefited from the support. The objectives of the awards were to strengthen the capacity of civic groups to advocate and implement the ideas and knowledge acquired during the training programmes, and to support their fund-raising activities. Civic groups and unions used the small grants for various projects, ranging from civic education programmes - such as the Parliamentary Candidates' debates in 2000 - to projects that focused on the need to prevent bush fire outbreaks and mechanisms to prevent such fires.

\section{Enhanced local government responsiveness to citizens' demands}

The third aim of ECSELL was to improve local government's response to citizens' demands. Local priorities differ between DAs and citizens, especially where citizens' participation in DA programmes is minimal. Consequently, ECSELL supported the DAs to be responsive to the demands of the local population, while also strengthening the capacity of civil society groups to engage with DAs through advocacy programmes.

Before the start of the ECSELL project, the DAs viewed civic groups as important stakeholders in good governance. The civic groups in these districts were seen as development partners that could provide alternatives to programmes modelled and implemented by DAs. The DAs had the discretion to recognise and legitimise such groups. For a group to be considered legitimate, it had to meet all DA-stated conditions of a patron-client relationship, such as the willingness to support the ruling political party and its programmes.

After the implementation of the ECSELL project, and as a result of the cordial interaction between CUs and DAs, in certain districts the CUs were given the mandate to mobilise taxes and DA rates from their members on behalf of DAs, on a commission basis. In Nadowli, this system worked very well. Each party adhered to the contractual agreement outlined in a memorandum of understanding (MOU), and the system served the interests of both parties. By contrast, in Ada, the Dangbe East DA did not adhere to the agreement. The CU members collected taxes on behalf of the DA but were not paid the agreed commission. This resulted in a series of incidents of civil disobedience by the CU. For example, during the 2000 financial year, no CU members paid taxes or other rates to the DA. According to the Dangbe East DA, the problem arose from poor communication between the outgoing and incoming District Coordinating Directors. 


\section{Government Accountability Improve Trust (GAIT) Project}

Improved collaboration between DAs and CUs to support good governance Before the GAIT project, most DAs and CSOs worked separately to achieve their primary objectives. Findings from the analysed data collected from the field showed that an estimated $56.8 \%$ of CSOs had no direct working relationship or official business with DAs. Among the respondents, 25\% said that there was a hostile relationship between the CSOs and the Assemblies, whereas only 20.3\% reported that some level of cordial relationship existed between the CSOs and the Assemblies.

After the start of GAIT, the relationship between the DAs and CUs improved. Only $14.9 \%$ of the CSO respondents reported that the CUs and DAs did not interact. This was a decrease of 41.9 percentage points from the $56.8 \%$ who had said the same thing before GAIT implementation. Reports of a hostile relationship between CSOs and DAs dropped from $25 \%$ to $2.7 \%$. Correspondingly, the atmosphere of cordiality improved tremendously, from the initial reported $20.3 \%$ to $82.4 \%$. The growth of cordial relations between DAs and CUs was mutually beneficial. It enabled civic groups to articulate their interests more easily, and ensured that DAs saw civic groups as valuable stakeholders for implementing government programmes and effective channels for mobilising revenue for the Assemblies.

\section{Participatory decision-making in development planning}

The GAIT project offered leadership training to CSOs and DAs as a way of involving stakeholders at the district level in the development process. As part of the training, leaders were educated about community opportunities and key responsibilities to benefit the community. The DA staff and CUs attended workshops together, which gave the CUs a chance to articulate community concerns to the DA. Once GAIT stopped operating in certain districts, postintervention evaluations by the study confirmed that the DAs had continued to work with CUs to consolidate the gains that had been achieved.

\section{Formation of networks and coalition-building among CSOs}

The GAIT project encouraged CUs to form networks beyond their communities to advocate on issues of mutual community concern. As a result, the Northern Network of Civil Society was established for the three Northern Regions: Upper East, Upper West and Northern. In the Volta Region, the Volta Regional Network of CUs (VONCU) was established to facilitate cooperation, the sharing of ideas, and regional problem-solving. The VONCU developed and signed an MOU with MPs from the Volta Region.

The National Network of CUs also emerged to campaign on issues raised at the regional or zone level, and brought them to the attention of the state. Networks 
also developed with specific organisations. In Wa and Bole, for example, CUs teamed up with Plan International and Adventist Development Relief Agency (ADRA) respectively, to undertake joint civic education programmes.

\section{Demanding accountability from the DAs}

Civic unions initiated several programmes aimed at promoting vertical accountability in local communities. These CUs began the process by actively contacting public office-holders, either individually or collectively, and communicating specific demands; at times this was backed by financial contributions.

Before the GAIT project, only $12.2 \%$ of CU members had a basic knowledge of the internal accountability structures of the DAs, and $12.3 \%$ of CU members directly demanded accountability from DAs (according to the Baseline Study conducted by IFES). Both transparency and accountability improved in various districts as a result of GAIT. For example, after GAIT advocacy programmes were set up in Techiman, the municipal DA began displaying the cost of all development projects from 2001 to 2004 on public noticeboards, to inform the general public about DAs' expenditure. The CU in Damango organised public informationsharing on various government policies, such as the Youth Employment Programme and the National Health Insurance Scheme.

The CUs used the most pragmatic means available to get answers from the DAs. These methods included letters and demand notices to their respective DAs, questions during 'Peoples DA' sessions, and questions during DA programmes. Such methods were used either individually or in combination. Findings from the survey indicated that letters written to DAs made up 55.8\% of all requests made to DAs. The CUs favoured letters because they allowed for easy follow-up, and helped to form relationships because discussions were held before the letters were actually sent. Some CSOs continued to use DAs' internal accountability structures - such as those on procurement, budgeting, and auditing procedure. However, there are legal limits to the involvement and extent of the use of such internal accountability structures.

\section{Participatory budgeting}

A participatory budgeting process has become an integral part of public administration, especially in developing countries. Integrating diverse interests is critical to successful budgeting. In a study of participatory budgeting in Porto Alegre in Brazil, Mehrotra (2006, p. 12) observed that such a process deepens democratic decentralisation, and improves output indicators of services delivered by the state. Although the GAIT project did not satisfy all the requirements for participatory budgeting, it made a significant contribution to the DAs' budgeting process. 


\section{Revenue mobilisation and financial dynamism}

The CUs introduced dynamic financial measures to bolster the DAs' revenue bases. In Bole, for example, government officials who lived in state bungalows without paying the requisite rent were compelled by CUs to honour their obligations to the DA. The DAs involved CUs in revenue mobilisation to show that CUs were seen as partners in development, and to emphasise the importance of working together. Findings from the study showed that the contributions made by the CUs to revenue mobilisation strengthened the relationship between those CUs and the DAs, and highlighted their progressive contribution to the communities which they served.

\section{Contributions to Districts' revenue bases}

The CU advocacy programmes administered through GAIT contributed a great deal to the Internally Generated Fund (IGF) of some districts. These CUs signed MOUs with their respective DAs to help in collecting revenue, with the CU receiving a small commission. This arrangement resulted in mutual revenue increases. As an incentive to CUs, the Assemblies appointed executive committee members of CUs into various DA committees.

\section{Promoting women in governance}

The women's wings of CUs took part in education campaigns on issues related to the Domestic Violence Bill. Women organised sensitisation workshops on topics affecting the well-being of women and children. These included testing for breast cancer, and girl child education. These advocacy campaigns by women were considered by the CSOs as successful because they created the required awareness of issues which had not previously been prioritised in the community.

The GAIT project encouraged equal opportunity for men and women to contribute to advocacy programmes. Findings from the study showed that $97.1 \%$ of survey respondents felt that GAIT was sensitive to the plight of women and provided equal opportunities for both men and women to engage the DA. This finding is highly commendable compared with the national governance matrix ratio of 1:9 in favour of men.

\section{Dialogue between citizens and Assemblies}

Through the CUs, the GAIT project bridged the gap between DAs and citizens. The initiative gave citizens information from the district level, and implemented programmes. In Wa, Nadowli, Bongo and Damango, suggestion boxes were placed in specific areas so that individuals could share their views on governance in the district with the DA (in the language of their choice). Public noticeboards were erected in Bole so that citizens could be kept in touch with progress and 
development in the district. In various districts, CUs engaged their DAs to provide social services to improve people's quality of life. Water was an engagement issue which permeated most districts and heightened the dialogue between citizens and DAs.

\section{ANALYSIS}

An impressive amount of funding was provided to IFES from USAID to implement both the ECSELL and GAIT programmes. However, the key results from these programmes arose from the practical outputs which CSOs gained from participating, rather than strictly economic development. The emphasis on skills development and increasing transparency and collaboration were clear benefits of the programmes. These outcomes highlight the importance of funding when channelled in the appropriate avenues.

While significant progress has been made in improving the democratic process in Ghana, questions remain about the sustainability of such progress. These questions arise because the projects have ended and so has the support both technical and financial - which they provided. What is evident from this study is that the financial aspect of the projects was highly important. Not only did they provide the funds and resources for people to participate in the programmes but they also offered clear objectives to work towards, and guidelines for targeting this work. Two pertinent questions are the following:

- Were the support mechanisms put in place by both projects strong enough to ensure continuation at the individual community level, or did temporary funding lead only to temporary success?

- Did project participants invest in the programme objectives to the extent that they will promote its longevity post-funding?

Ultimately, such questions emphasise the importance of effective project planning regardless of where the project's funding may originate. The success in implementing both projects illustrates the importance of a number of elements related to both project management and funding, especially with regard to sustainability. This study found discrepancies in the levels of transparency and collaboration between communities that were involved in the projects and those that were not. Such discrepancies highlight the need to implement project elements on a large scale and ensure that key lessons are well learnt and reinforced.

The CUs proved highly effective at bridging the gap between the DAs and the citizenry. They served as a common platform where divergent opinions based on occupational and sectional interests could be aggregated. The CUs also made 
it easier for citizens to demand accountability from public office-holders who had been elected and appointed, and facilitated dialogue between the DAs and citizens to ensure transparency. Generally, the CUs became an umbrella body through which civil society could engage with the state and participate in local governance. This led to greater accountability, transparency, and improved governance.

Institutionalising the $\mathrm{CU}$ concept throughout the country, and extending the concept to all 170 districts in Ghana, could have been an essential part of initial project planning. That the project did not incorporate this aspect, but instead gathered data for reporting on democracy growth within civil society in Ghana, seems to demonstrate the short-sighted nature of some US aid projects.

Bräutigam (2000) argues that aid programmes require clear leadership if they are to be sustainable. According to Bräutigam providing such leadership is challenging, especially in a constrained donor and resource environment. Both the ECSELL and GAIT projects showed that although people were often eager to take on CU leadership roles, sustaining the enthusiasm and momentum of civic interaction in local governance was extremely challenging. Arguably, some leaders were merely seduced by the power and stature of their prospective positions. Over time, fervour in demanding accountability tended to wane as leaders began to taste the benefit of integrating into the inner DA systems.

Currently, CU leaders do not have tenure of office and are seen as 'emperors' who are unwilling to share their power or hand over their responsibilities, irrespective of their ability and availability. Additionally, the transfer of power and responsibilities within CUs poses a huge challenge for CU leadership. In Bole, for example, four key executive members left the town to pursue personal development opportunities (education, marriage, and employment) without handing over their responsibilities. In Berekum, three core executive committee members left the union without being replaced. Such events created a vacuum and caused the loss of institutional memory for future generations of CU leaders. As a result the new executive committee had to reinvent the dialogue process with DA.

Thus, it is important to have a defined tenure of office for CU leaders and a mechanism of transfer of power and responsibilities amongst CU members. Without these clear leadership roles and terms of reference for exchanges of power, the same corruption that plagues many national governments across Africa will continue to exist at the local level too.

A further challenge to the continuity and independence of a successful project is the issue of sustainable funding. Critics of donor aid projects cite the sudden loss of resources at a project's end, without adequate avenues for potential support or self-sustaining resources, as a major oversight among development practitioners (Dichte 2003; Kosack 2003; Riddell 1987). Both the ECSELL and GAIT projects ran into this problem. 
A possible solution would have been to integrate economic opportunities into the projects, with the aim of building the economic capacity of $\mathrm{CU}$ members. This could have improved their financial status and ensured a higher level of commitment to the programme. For example, in similar local governance programmes such as the Local Regional Economic Development (LRED) implemented by German Technical Cooperation (GTZ), suitable methods of harnessing local resources to generate income were integrated into the programme; this empowered the communities economically as well as politically. The integration of economic opportunities into programmes would ensure that $\mathrm{CU}$ members who invest their time in advocacy programmes will reap economic dividends. This would be an incentive to continue their efforts. The narrow focus of both IFES projects (ECSELL and GAIT) on political transparency, accountability and collaboration has neglected the interdisciplinary reality of political systems. Political systems do not stand alone, but function in an interconnected way with social and economic systems.

In addition to programme-specific concerns, central to the debate on democratisation aid is the issue of an exit strategy. This study found that America's contribution to Ghana's development process was not only substantial, but in the case of the ESCELL and GAIT projects was highly effective in building active collaboration and transparency, and helping citizens to understand their rights to such processes. However, there is little evidence of sustainable and systemic change strategies after the end of the project cycle. Stark criticism of quick exit strategies, which lead to limited project outcome follow-through, continues to plague many American-funded projects in Africa.

Engagement with the staff of USAID showed that the current exit strategy implemented by USAID is detrimental to the development of a dynamic civic advocacy culture, because it lacks three key exit processes:

- a mutually agreed upon end date, and a procedure for exit by key stakeholders;

- strategies and supports for project sustainability; and

- effective transfer of responsibilities through selecting a new project leader.

Both the GAIT and ECSELL projects were withdrawn without concern for the above processes. This led to a mass layoff of staff and national service personnel. Without developing a clear exit strategy which is effectively communicated to successive leaders, avenues for growth and further development remain limited at best. 
Khang and Moe (2008) argue that an effective project management cycle is one that, overall, represents clarity - specifically in terms of leadership, terms of reference, and subsequent funding. In the case of both ESCELL and GAIT, these elements were overlooked. To build on the programmes' successes, new project leaders should have been identified and training needs should have been appropriately provided. Subsidiary stakeholders should also have been identified, and relationships and terms of reference between stakeholders and clear monitoring and evaluation systems should have been developed. In addition and perhaps quite obviously, opportunities should have been determined for funding the project after the withdrawal of American funds. Thus the issues surrounding democracy aid are not so much funding in the case of Ghana's ESCELL and GAIT projects, but their limited focus on sustainability, and their limited scope.

\section{CONCLUSION}

This study has shown that foreign financial and technical support can serve as a catalyst for empowering CSOs to become more active participants in development and democratic processes. In both the ECSELL and GAIT programmes, this contribution and collaboration was the driving force to achieve a higher level of democracy, such as improved transparency and accountability from government stakeholders to their constituents.

The ECSELL project also led to the formation of CUs. These CUs bridged the gap between the community and DAs, and served as a link between the DAs and various civil society groups. This led to a convergence of interests between various decentralised departments and communities' needs. The effective formation of CUs, their contribution to communities, and the community and local government support they received seem to address a long-held challenge to democratic development. Ninsin (1993, p. 184) articulates this as the notion that low economic status prevents sovereign citizens from ensuring that their representatives are responsive and accountable. Certain aspects of Ninsin's (1993) proposition - such as mass illiteracy, ignorance and superstition - continue to remain threats to democratic development in Ghana. However, the financial and technical support which CUs received from USAID greatly enhanced the participation of those CUs in the democratic process at the local level, and thus enhanced the country's overall democracy.

Ultimately, the support given by USAID, both financial and technical, ensured the active formation of CUs in project districts. This in turn enhanced the democratisation of those districts. The formation of CUs is yet to be seen in non-project districts, and the spectrum of democracy remains limited. This fact alone suggests the importance of such aid and programme planning. 
The gains made in democratic development by civil society through CUs further challenge those theorists who suggest that granting democracy aid to civil society yields poor results. For example, Carothers and Ottaway (2000), Hearn (2003, p. 22) and Brown (2005) suggest that the democratic outcomes and dividends derived from such investments are disappointing. By contrast, this study showed that the advocacy responsibilities entrusted to CUs by civil society actually helped to improve the relations between CSOs and DAs in the project's districts. These improved relationships enhanced the local government's responsiveness to citizens' demands and community concerns.

In the districts of Techiman and Berekum, the CUs and DAs would collaboratively bid for projects. This type of enhanced relationship affirms Gaventa's (2004, p. 10) assertion that with appropriate support, citizens and governments can collaborate in new ways. By doing so they are able to participate, deliberate and develop solutions to pressing social, economic and community development issues. Such collaboration improves citizens' ability to make informed political choices. It also provides a platform for civic education programmes on various government policy directions.

In the ECSELL and GAIT project areas, the CUs participated in preparing district budgets and in revenue mobilisation. The improved relations between DAs and CUs contributed to the strengthening of local governance in these districts. Budgets were based on the needs of the community. Challenges to revenue mobilisation were addressed as CSOs and DAs became partners, and CSOs became community agents to sensitise citizens about revenue mobilisation. Ultimately, the level of transparency and accountability in project-area DAs was considerably improved.

This study identified several areas of engagement between the CUs and the DAs, ranging from participation to financial mobilisation and from performance monitoring to accountability. The GAIT project rejuvenated an effective accountability system in DAs through the CU programme. Budget hearings were conducted with diverse stakeholders before DAs' approval. As part of the drive to improve accountability through transparency, as espoused by Broz (2002, p. 1), analyses of various DA budget estimates were made by relevant stakeholders. The CUs were able to monitor and assess the implementation of various components of the budget. This contributed to the prudent use of public resources, which in turn led to greater effectiveness and efficiency - which are critical virtues in public administration.

The CUs further encouraged the DAs to publish, on public noticeboards, the cost of projects they had executed. This publication served as the basis to investigate projects which might, in the view of civil society, give public officeholders the chance to engage in financial malfeasance. Access to such critical 
information enabled civil society to hold DAs accountable for the use and management of public resources. The DAs responded to the CUs' demands by providing a number of social services to communities. Fulfilling community aspirations is a critical index to measure whether democracy is on track (Papadopoulos 2007, p. 2). The formation of CUs strengthened civil networks and made sure that community needs featured in the political schema.

As this paper has shown, USAID support in the form of technical and financial resources has contributed significantly to the democratisation of Ghana's civil society. What is emphasised is the importance of foreign aid in the democratisation of Ghana's Fourth Republic. Despite this conclusion, however, further research is needed on certain aspects of democracy aid. For example, there are 'missing elements' that require better understanding, such as the impact and influence of donor assistance on the priorities of governments and citizens alike. As noted earlier, there is a real propensity for people to take advantage of positions of power, and such enticement is serious in a constrained donor and resource environment.

Leaders in developing countries have to make difficult choices between either financing democracy and its related institutions, or financing other pressing social services such as security, education, health, water and infrastructure. The picture is complicated by the rampant corruption that has plagued many nations' pasts, and in some cases continues to constrain democratic development. Thus, foreign aid is especially critical where the cost and sophistication of democracy have become extremely high.

The hypothesis of this study was that USAID democratic support, in the form of ECSELL and GAIT projects at the local level, enhanced the formation and operation of CUs; and that this in turn improved civil society activism at the local level in Ghana. After weighing the evidence presented in this paper, the author believes that this hypothesis has been supported. This would affirm the position held by financial transfer theorists. Financial transfer theory posits that aid is able to influence the governance structure of a society and country by enlarging the political space for citizens to participate in their own affairs.

Ghana, as it officially becomes a middle-income country, is faced with the additional challenge of managing a fast-growing economy, indeed the fastestgrowing in West Africa. This growth must be balanced against equally fastgrowing inequalities in the social, political and economic spheres. Faced with these realities, democratic principles - such as transparency, accountability, and collaboration between civil society and the state - are all the more pertinent. If Ghana is to continue to hold its successful international designation as a 'stable democracy' and middle-income country, it must ensure that the aid it receives is tied to the conditions of sustainability, longevity and skills development for 
a $21^{\text {st }}$ century knowledge economy. Without these elements, real and practised democratic processes will be limited to the funding that promotes them. The far more preferable option is to grow a culture and constituency that is selfsustainable and self-empowering, with people who are active agents in their own development processes.

\section{- REFERENCES}

Al-Momani, HM 2003, Financial transfer and its impact on the level of democracy: a pooled cross-sectional time series model, University of North Texas, Texas.

Almond, G \& Powell, GB 1966, Comparative politics: a developmental approach, Little Brown and Company, London.

Almond, G \& Verba, S 1963, The civic culture, Princeton University Press, Massachusetts.

Apodaca, C \& Stohl, M 1999, 'United States human rights policy and foreign assistance', International Studies Quarterly, vol. 43, no. 1, pp. 185-98.

Boafo-Arthur, K 2008, Democracy and stability in West Africa: the Ghanaian experience, Claude Ake Memorial Papers No. 4, Uppsala University.

Boafo-Arthur, K 1998, 'The International community and Ghana's transition to democracy', in Ghana: transition to democracy, Freedom Publications, Accra .

Boafo-Arthur, K 1993, 'Political parties and prospects for national stability', in K Ninsin \& K Drah (eds), Political parties and Ghana's Fourth Republic, Woeli Publishing Services, Accra, pp. 224-45.

Brands, HW 1998, What America owes the world: The struggle for the soul of foreign policy, Cambridge University Press, Cambridge.

Bräutigan, D 2000, Aid dependence and governance, Almqvist and Wiksell International, Stockholm.

Brown, S 2005, 'Foreign aid and democracy promotion: Lessons from Africa', European Journal of Development Research, vol. 17, no. 2, pp. 179-98.

Broz, LJ 2002, 'Political system transparency and monetary commitment regimes', International Organisation, vol. 56, no. 4, pp. 861-87.

Brysk, A 2000, 'Democratising civil society in Latin America', Journal of Democracy, vol. 11, no. 3, pp. 151-65.

Camerer, L 2000, 'Terms of Endearment: Bilateral donor engagement in fight corruption in South Africa', African Security Review, vol. 9, no. 5/6, pp. 3-14.

Campbell, N, Davis, J \& McKay, G 2004, 'Conclusions: globalisation, Americanisation and the New World Order', in N Campbell, J Davis \& G McKay (eds), Issues in Americanisation and culture, Edinburgh University Press Ltd., Edinburgh, pp. 295-307.

Carothers, T 2000, 'Taking stock of democracy assistance', in M Cox, GJ Ikenberry \& 
T Inoguchi (eds), American democracy promotion: impulse, strategies and impacts, Oxford University Press, Oxford, pp. 181-99.

Carothers, T 1997, 'Democracy Assistance: The question of strategy', Democratisation, vol. 4, no. 3, pp. 109-32.

Carothers, T \& Ottaway, M 2000, 'Funding virtue: civil society aid and democracy promotion', Brookings Institution Press, Washington.

Chabal, P1998, 'A few considerations on democracy in Africa', International Affairs, vol. 74, no. 2, pp. 289-303.

Clapham, C 1993, 'Democratisation in Africa: obstacles and prospects', Third World Quarterly, vol. 14, 3, pp. 423-38.

Crawford, G 2001, Implementing political aid programmes in foreign aid and political reform: a comparative analysis of democracy assistance and political conditionality, Palgrave, New York.

Crook, RC 1994, 'Four years of the Ghana district assemblies in operation: decentralisation, democratisation and administrative performance', Public Administration and Development, vol. 14, no. 4, pp. 339-64.

Dahl, R 1997, 'Development and democratic culture', in L Diamond (ed), Consolidating the third wave democracies: themes and perspectives, John Hopkins University Press, Baltimore, pp. 34-39.

Diamond, L 2004, 'Promoting real reform in Africa' in E Gyimah-Boadi (ed), Democratic reform in Africa: the quality of progress, Lynne Rienner Publisher, Colorado, pp. 263-82.

Diamond, L 1999, Developing democracy: toward consolidation, John Hopkins University Press, Baltimore.

Diamond, L 1992, 'Economic development and democracy reconsidered', American Behavioral Scientist, vol. 35, no. 4/5, pp. 450-99.

Dichte, TW 2003, Despite good intentions: why development assistance to the third world has failed, University of Massachusetts Press, Massachusetts.

Djankov, S, Montalvo, J \& Reynal-Querol, M 2008, 'The curse of aid', Journal of Economic Growth, vol. 13, no. 3, pp. 169-94.

Drah, K 1993, 'Civil society and the transition to pluralist democracy', in K Ninsin \& K Drah (eds), Political parties and democracy in Ghana's Fourth Republic, Woeli Publishing Services, Accra, pp. 72-115.

Dunning, T 2004, 'Conditioning the effects of aid: Cold War politics, donor credibility, and democracy in Africa', International Organisation, vol. 58, pp. 409-23.

Evans, G 2006, 'From humanitarian intervention to the responsibility to protect', Wisconsin International Law Journal, vol. 24, no. 3, pp. 703-22.

Finkel, SE, Pérez-Liñán, A \& Seligson, MA 2007, 'The effects of US foreign assistance on democracy building 1990-2003', World Politics, vol. 59, pp. 404-39.

Gaventa, J 2004, 'Strengthening participatory approaches to local governance leaning the lessons from abroad', National Civic Union Review (winter ed), pp. 16-27. 
Gerald, G 1966, 'Foreign aid theory: where do we go from here?' World Politics, vol. 18 , no. 4, pp. 735-48.

Goldsmith, A 2001, 'Foreign aid and statehood in Africa', International Organisation, vol. 55 , no. 1 , pp. 123-48.

Gyimah-Boadi, E 2004, 'Introduction', in E Gyimah-Boadi, (ed), Democratic reform in Africa: the quality of progress, Lynne Rienner Publishers, London, pp. 1-4.

Hansen, G 1996, Constituencies for reform: strategic approaches for donor-supported civic advocacy programs, USAID Program and Operations Assessment Report (12).

Hanson, JR 1991 'Third world incomes before World War 1: further evidence', Explorations in Economic History, vol 28, issue 3, pp 367-379.

Haynes, J 2003, 'Democratic consolidation in Africa: the problematic case of Ghana', Commonwealth and Comparative Politics, vol. 41, no. 1, pp. 48-76.

Hearn, J. 2000. 'Aiding democracy? Donors and civil society in South Africa', Third World Quarterly, vol. 21, no. 5, pp. 815-30.

Hearn, J 1999, Foreign aid, democratisation and civil society in Africa: A study of South Africa, Ghana and Uganda, Discussion paper no. 368, Institute of Development Studies, University of Sussex, United Kingdom,

Huntington, SP 1993, The third wave democratisation in the late twentieth century, University of Oklahoma Press, Norman.

IFES, 1999, Report of baseline study on management practices of civil society organisation, Research International (Ghana Ltd), Accra.

Inglehart, R 1988, 'The renaissance of political culture', American Political Science Review, vol. 82, pp. 1203-30.

International Foundation for Election Systems (IFES), 2006, Report of Assessment of Support to Civil Society.

Jamieson, D 2005, 'Duties to the distant: aid, assistance, and intervention in the developing world', The Journal of Ethics, vol. 9, pp. 151-70.

Karl, TL 1997, The paradox of plenty: oil booms and petro-states, University of California Press, Berkeley.

Khang, DB \& Moe, TL 2008, 'Success criteria and factors for International development projects: a life-cycle based framework', Project Management Journal, vol. 39, no. 1, pp. 72-84.

Knack, S 2004, 'Does foreign aid promote democracy?' International Studies Quarterly, vol. 48, no. 1, pp. 251-66.

Kosack, S 2003, 'Effective aid: how democracy allows development aid to improve the quality of life', World Development, vol. 31, no. 1, pp. 1-22.

Leonard, DK \& Scott, S 2003, Africa's stalled development: international causes and cures, Lynne Rienner, Boulder Colorado.

Lipset, SM 1959, 'Social Requisites of Democracy: economic development and political legitimacy', American Political Science Review, vol. 53, no. 1, pp. 69-105. 
Lowenthal, A 1991, The United States and Latin American Democracy: learning from history, Johns Hopkins University Press, Baltimore.

Mehrotra, S 2006, 'Governance and basic social service: ensuring accountability in service delivery through deep democratic decentralisation', Journal of International Development, vol. 18, no. 2, pp. 263-83.

Midlarsky, M 1989, Handbook of war studies, University of Michigan Press, Ann Arbor. Monten, J 2005, 'The roots of the Bush doctrine: power, nationalism, and democracy promotion in US strategy', International Security, vol. 29, no. 4, pp. 112-56.

Ninsin, K 1993, 'The electoral system, elections and democracy in Ghana', in K Ninsin \& K Drah, (eds), Political parties and democracy in Ghana's Fourth Republic, Woeli Publishing Services, Accra, pp. 175-191.

O'Donnell, G \& Schmitter, PC 1986, 'Negotiating (Renegotiating)', in G O'Donnell \& P Schmitter (eds), Transitions from authoritarian rule: tentative conclusion about uncertain democracy, John Hopkins University Press, Baltimore, pp. 37-47.

Olson, M 1993, 'Dictatorship, democracy and development', American Political Science Review, vol. 87, no. 3, pp. 567-76.

Papadopoulos, Y 2007, 'Problems of democratic accountability in network and multilevel governance', European Law Journal, vol. 13, no. 4, pp. 447-68.

Pearce, J, Freeman, E \& Robinson, RB 1987, 'The tenuous link between formal strategic planning and financial performance', Academy of Management Review, vol. 12, no. 4, pp. 658-75.

Przeworski, A1986, 'Some problems in the study of the transition to democracy', in G O' Donnell, PSchmitter \& L Whitehead (eds), Transition from authoritarian rule: comparative perspectives, John Hopkins University Press, Baltimore, pp. 47-63.

Quan, L \& Adam R 2003, 'Reversal of fortunes: democratic institutions and foreign direct investment inflows to developing countries', International Organisation, vol. 57, no. 1, pp. 175-211.

Regan, P 1995, ‘US economic aid and political repression: an empirical evaluation of US foreign policy', Political Research Quarterly, vol. 48, no. 3, pp. 613-28.

Riddell, RC 1987, Foreign aid reconsidered, Overseas Development Institute.

Rustow, D 1970, 'Transition to Democracy: toward a dynamic model', Comparative Politics, vol. 2, no. 3, pp. 337-363.

Santiso, C 2000, 'Towards democratic governance: the contribution of the multilateral development banks in Latin America', in P Burnell (ed), Democracy assistance international co-operation for democratisation, Frank Cass Publishers, United Kingdom, pp. 150-190.

Szeftel, M 1998, 'Misunderstanding African Politics: corruption and the government agenda', Review of African Political Economy, vol. 25, no. 76, pp. 221-40.

Talentino, K 2005, Military intervention after the Cold War: the evolution of theory and practice, Centre for International Studies, Ohio University Press, Ohio. 
USAID Report of Assessment of Effects of US Foreign Assistance on Democracy Building 1990-2003 (pdf.usaid.gov/pdf_docs/ Pnades694. Pdf).

Vanhanen, T 1990, The process of democratisation, Crane Russak, Washington, DC.

Whitehead, L 2002, Democratisation theory and experience, Oxford University Press, Oxford.

Whitehead, L 1991, 'The imposition of democracy', in A Lowenthal (ed), Exporting democracy: themes and issues, John Hopkins University Press, Baltimore, pp. 216-42.

Williamson, J \& Stephen, H 1994, 'The political conditions for economic reforms', in J Williamson (ed), Political economy of policy reform, Institute for International Economics, Washington, pp. 525-96. 